\title{
Can E- Commerce Enable Marketing in an African Rural Women's Community Based Development Organisation?
}

\author{
Jo Rhodes \\ University of Capetown, South Africa
}

|rhodes@commerce.uct.ac.za

\begin{abstract}
The World Bank Development Report (2000) findings show that at the macro level the most effective anti poverty policies are those that achieve equity through redistribution whilst simultaneously enhancing the efficiency of the markets used by poor people. It also found that even if markets work, poor people need assistance to overcome the obstacles that prevent them from freely accessing markets on an equal basis with other business groups. Investment in infrastructure and modern technologies such as ITC's may break down some of the barriers of access such as physical remoteness and are cited by the World Bank as a potential solution to creating market access. However there is little existing research that examines this scenario at the micro level. This paper uses a case study- the Rural Women's Association (RWA) of Sekhuhkuneland, Northern Province, South Africa to examine if E- commerce can enable access to markets in a impoverished, under resourced rural location. This paper has 5 parts: Part 1 consists of the background and rationale for this study, Part 2 focuses on the education, business acumen and gender issues. Part 3 discusses the current market environment. Part 4 discusses possible business models that can integrate e-commerce in its implementation. Part 5 provides the research questions and the methodology for this study. The final discussion in this study provides us with a viable e-commerce model that could be used in a rural setting and could provide greater economic development for this community.
\end{abstract}

Key words: e-commerce, marketing, rural economic development, gender

\section{Introduction}

Although rural communities tend to be poorer because of physical isolation, the World Bank development report findings (2000) suggest that the most effective anti poverty policies are new activities that could enhance the marketing of rural communities products and services. The World Bank report further submits that new technologies can help (especially Information technologies) in breaking down some of the remoteness that many rural people face. Cypher (1997, p.402) remarks that " the significance of technological change to economic growth and development has been verified again and again in empirical studies" and that research points to a "residual" (which includes technology) that contributes over and above the basic factors of production to increased productivity. It is the intention of this pa-

Material published as part of this proceedings, either on-line or in print, is copyrighted by the author with permission granted to the publisher of Informing Science for this printing. Permission to make digital or paper copy of part or all of these works for personal or classroom use is granted without fee provided that the copies are not made or distributed for profit or commercial advantage AND that copies 1) bear this notice in full and 2) give the full citation on the first page. It is permissible to abstract these works so long as credit is given. To copy in all other cases or to republish or to post on a server or to redistribute to lists requires specific permission from the author. per to use the Rural Women's Association (RWA) of Sekhukhuneland to explore one of the poverty alleviation concepts suggested by the World Bank, that is, whether Ecommerce can enhance marketing to provide greater economic benefits to rural communities.

\section{Background}

In 1992 Sister Lydia Pardeller of the Franciscan order of nuns was charged with locating the "poorest of the poor" community in South Africa to facilitate improvement in the lives of women and children. Her search led her to the village of Apel in Sekhukhuneland, Northern Province South Africa. The area is characterised by extreme poverty with the highest unemployment rate in the country (estimated at around $70 \%$ ). The migrant labour force (a remnant from the apartheid era) remits paltry wages back to their families in the village. The task of improving the quality of life falls mainly on the shoulders of the women who remain resident in Apel.

Eight years after the RWA launch in 1992 the women of Apel have significantly improved their lives. Tangible success indicators and determinants showing evidence of sustainable economic development are documented (Rhodes 2000). 
In 1998 The RWA was the recipient of a Universal Service Agency (USA) Telecentre (an initiative resulting from the 1996 South African Telecommunications Bill) which provided computers, telephones, fax, photocopying and the Internet. Telecentres are believed to be the vehicles through which micro and small enterprises can seek out and evaluate timely market information as well as assist micro entrepreneurs to source better and less costly inputs (NTCA).

\section{The Market Environment}

Research in the rural district of Semonkong, Lesotho (Phororo and Prasad) where $61 \%$ of farmers are female and $70 \%$ of produce is farmed in home gardens identified marketing weakness as the major constraint to expanding economic activity.

Similarly the women of Apel are struggling to increase economic activity in the face of an undeveloped market place, no transport and bad roads. There is no physical market in the Sekhukhune region and as the RWA has no transport facilities all produce and goods are sold locally (within a couple of kilometres).

\section{Education, Information Technology and E-commerce}

Rural women in Africa are generally not highly educated and there is an obvious gap in their understanding of business models and information technology and its potential benefits to the community. This is clearly demonstrated in their inability to utilise the telecentre effectively. It has been reported (Richardson 2000) that women with access to ICT services increase their ability to generate income and are enabled to help empower other rural women. Also, it has been recommended (AFRE-FEM 1998) that there is a crucial need for programmes that target women for improved ICT access and training and the use of Internet applications.

The women are relatively new to business concepts and have little experience of how to identify and develop markets. They have no information on average produce and goods prices and do not know the value of their crops and goods or what crops and goods are in demand. Information on who wants to buy what and who has what to sell is scarce. Generally the produce and goods are sold at low prices and the economic activity in the area does not result in significant poverty eradication.

\section{Gender issues}

The RWA focuses on female economic empowerment as women in South Africa have been triply oppressed (black, female and poor) and are still generally on the bottom of the inequity pile in the country. Mchombu (2000) found that women have fewer opportunities to exchange information than men do and that often their information needs are tied to their cultural roles as homemakers and mothers. She found that women obtain most of their information through informal channels. She states that the lack of awareness of formal information resources is stymieing women's potential to succeed. Heeks (1999) notes that this information can be inaccurate, is incomplete and that turning raw data into useable information is a staged process.

\section{E- commerce definition}

E-commerce in the context of this discussion is defined as any form of business transaction where the buyers and suppliers connect electronically and by so doing enhance business efficiency through lowering transaction and communication costs. Increasing business effectiveness through widening market potential and better meeting customer needs whilst providing opportunities for enhanced product and service innovation. This inclusive and broad definition has been derived from a number of readings and in particular Timmer (2000), Turban et al (2000) Rappa (2000) and Cunningham (2000). It is clear that E-Commerce is based on several disciplines (e.g. marketing, finance, economics and organisation development).

\section{E-commerce Business Models}

Recent literature on E- commerce has discussed issues such as how trade can be enabled electronically; how speed in E-commerce can enhance trading activities; how Ecommerce can link producers and consumers more effectively and how remote communities can benefit in using these tools. The potential benefits of various E-commerce models will be examined to assess the potential power of ICT's that can be used by the RWA to enhance business activities.

E-Commerce has evolved rapidly over the last 5 years through a succession of business models and approaches, with each model being seen as viable for only a limited time. Business models for E- Commerce are based on the assumption of the flow of product, service and information. The sources of revenues and benefits for suppliers and customers are analysed using the value chain construction and de-construction principles. Timmers (2000) provided 11 business models or generalisations of specific models in his 


\section{Marketing in African Rural Women's Organisation}

discussion on E-commerce. These models can be mapped with 2 dimensions (qualitative mapping). The innovation dimension focuses on marketing approaches that have been translated from the physical world to cyberspace. The integration dimension focuses the information functions along the value chain.

Value chain construction and deconstruction is used as a systematic approach to identifying architectures for business models and then identifies possible ways of integrating information along the value chain. Porter (1985) identifies nine elements in value chain deconstruction. These are inbound logistics, Operations, Outbound logistics, Marketing and sales, Service, Technology development, Procurement, Human resource management and corporate infrastructure.

In the development of E-commerce models, certain trends have been observed in recent years. That is:

1. A move towards increased integration of information flows e.g. the integration of transaction handling functions into industry malls

2. The increasing development of specialised highly innovative services, e.g. specialisation in information brokerage or trusted third party services

3. Offering related products and services

4. E-shops are upgrading their services by adding online payment support. This added functionality goes hand in hand with increased integration where say customer data from one part of an online application is used in another part (cross sales).

5. Trust provision is expected to become increasingly important as a global service.

Business models tend to rely heavily on advertising revenues, the expectation was that a large part of corporate non Internet advertising would move to the Internet. Initially exponential growth of advertising revenues seemed to confirm this. Now there are strong indications (Rayport 1999) that this is now slowing down. Therefore these models may start encroaching on information subscription and transactions fees, and in doing this will move in the direction of the third party market place providers. (ISPs look favourably at this model). These business models are not always mutually exclusive e.g. virtual communities lend themselves to being combined with most of the other models. Furthermore, E-commerce can generate the ideal of perfect competition. That is,

1. Barriers to entry are lowered

2. Transaction costs are reduced

3. Customers have improved access to information
4. Marginal or customer orientated pricing becomes possible

5. Minimal legislation and regulation and other forms of intervention by public authorities exist

However, it also brings new barriers to entry. E-commerce requires greater capability to manage complex business relationships and there are plenty of new opportunities for new intermediaries who can shift the focus away from pure price competition. Furthermore, bypassing intermediaries has implications for cost reduction as well as being linked to competitive strategy. However, in the development and implementation phases, particular attention has to be given to areas such as leadership, knowledge and skills in information technology, the level of computer literacy, physical resources and support, training and development, scalability and sustainability.

There is little clear-cut evidence as to how the web changes traditional business models. That is, the business model spells out how a company makes money by specifying where it is positioned in the value chain. The web will give rise to new business models but is also likely to reinvent tried and true models

\section{The Internet retail model}

In the area of $\mathrm{B}$ to $\mathrm{C}$ commerce, a common example would be in the area of Internet retailing or "e-tailing" which covers a variety of different technologies or media. For example, the use of emails, on-line catalogues, home web page, on-line ordering and billing systems. Chen and Leteney (2000) commented that key issues facing B to C commerce would be:

1. What information to provide? How much? (what product range to offer)

2. How to personalise communication?

3. How to speed up processing of orders? How to exchange information with suppliers and distributors?

4. How to ensure prompt and reliable supply?

5. How to handle large volumes quickly and reliably?

As to the RWA's operation, the e-tailing via the telecentres can be enhanced if there is an Internet service provider who can ensure the technical reliability of the system. Since the RWA needs to target big customers in the cities, it is critical that this provider could also provide the training and latest support to the RWA.

Apart from the B to C commerce, the RWA could also utilise the network provided by the Internet service provider to expand into B-to-B commerce. All possible suppliers can be linked into the RWA system to create a significant size. 
These suppliers may provide direct supply to the customer if the distribution logistic system is set up effectively. Distribution is critical in E-commerce. It must be done on time with the correct quality to gain consumer confidence. In both B-to-C and B-to-B, the Internet service provider could absorb the start up costs but charge the user for each transaction.

\section{The current status of E- commerce}

Whilst Dot-coms may be going down in flames every day a new group of Web survivors is emerging unscathed (Weintraub 2001). These are known as the "mighty mini dots" and are generally small businesses. These companies are actually making money on the net. The mini dots are succeeding by sticking to tried and tested small business strategy (e.g. targeting niches, not pursuing expensive portal deals and scrimping on expenses). As much as $10 \%$ of gross domestic product in the USA is expected to come from these mighty mini-dots by 2004 .

\section{Research Questions}

It is the intention of this study to provide a viable business model in which E-commerce activities could enhance marketing activities of product and services and result in greater economic development in rural communities.

1. Can the existing telecentre infrastructure (human and technical) be used to develop E-commerce activities in rural communities, which can enhance marketing?

2. What are some of the barriers in the implementation of a business model of E-commerce for African rural women?

\section{Methodology}

The integration of Hartman and Sifonas infomediary model (Appendix 2) and Kotler's (1976) marketing principles (Appendix 1) is used as a base of discussion in this study. Although there are other issues such as political, social and financial factors, that can also influence the economic outcomes of women in rural areas, it is the intention of this study to focus only on the effect on the integration between E-commerce business models and marketing principles. The author through extensive interviews with the four RWA co-ordinators obtained qualitative data around perceptions on ICT and marketing. Results of the data analysis identify the strengths and weaknesses of current activities in the RWA. Furthermore, the activities generated by the Ecommerce and marketing frameworks used in this study could provide us with the strategy to transform the current self-sufficient status to a more dynamic economic growth phase that will increase the economic benefit for rural women.

\section{Results of data analysis}

Qualitative analysis of interviews with the 4 key players (RWA executive members) reviewed that there are strengths and weaknesses in the current operation of the RWA (Table 1). In this study, we have focussed mainly in the area of weaknesses. The contribution of strengths in the RWA operation has not been ignored but despite the success of generating sustainable income for the RWA members, there is minimal economic improvement.

The above findings point to 3 major areas of weaknesses in the current RWA operation. These are 1 . There is no integration of community information based on the telecentre operation, 2. There is a lack of knowledge in business acumen and marketing principles and 3 . There are insufficient leadership and management skills.

\section{Discussion}

The RWA telecentre as a vehicle for a community information system (CI) has not yet succeeded in any substantial way. Whilst it has begun to generate some income through the provision of local software training programmes the centre has not made significant inroads into reaching break-even point and has not improved the general economic situation among women. The centre is still underutilised at present. All the RWA executive members have some understanding of what the Internet and email are and how these could be employed to enhance their business activities. However, there is little understanding on how to action these ideas and the use of the Internet and email for improving their businesses is not linked in the minds of the women with the telecentre operation. The training of the two RWA telecentre managers has been minimal. Since the initial training, there has been limited support and guidance on how the telecentres resources can be used efficiently and effectively. In order to fully integrate CI into the system and to maximise its value to the community, it is necessary to examine a telecentre service delivery system that would include the following (Gurstein 2000).

1. A community-based technical capability to receive service and interpret information - In order to operate the telecentre effectively, the centre needs to have a minimum level of connectivity (i.e. user friendly, minimal learning and training time) and technical skill for ongoing management and maintenance. Although the RWA leadership has the basic training to operate the 


\section{Marketing in African Rural Women's Organisation}

\section{Strengths}

1The RWA has an excellent reputation in the area of providing quality products and services to the community

2. The RWA has the backing and endorsement of all the local chiefs

3. The RWA has been included in the USA telecentre project sponsored by the government

4. The RWA has achieved legal documentation of land agreements

5. The new RWA board has the right to appoint the leadership role in the RWA

6 . The RWA will only consider respondents who prove commitment through initiating projects

7. Substantial gender power in a patriarchal environment

\section{Weaknesses}

\section{- telecentres community information}

1. Lack of understanding in the application of community information e.g. the possible benefits that the telecentres can provide

2. The telecentre managers do not have the opportunity to extend the knowledge, skills and potential benefits of its services to the local producers

3. Lack of understanding of the potential benefits of community e-commerce and the relative importance of an Application Service Provider (ASP).

- marketing

4. Lack of knowledge in marketing and market research and e-commerce/community information potential

5. Insufficient understanding of how the marketing model works

6 . Inability to determine customer needs and create competitive advantage (market information)

- management structure

7. Historically the RWA has no formal budgeting procedures

8. No structured program to train champions and no follow up of these champions

- leadership

9. Sister Lydia Pardeller (the founder) recently left the RWA. There is an urgency to bridge the capability gap caused by her departure.

Table 1: Strengths and weaknesses of current RWA operation

the technical aspects of the centre it has been unable to develop models to improve the local trading opportunities. The services of the telecentre have not been widely marketed to the community and the limited marketing has not focussed on how local trading opportunities can be improved. Furthermore, the lack of skills in identifying, interpreting and usefully translating market information to the local population, (which has varying levels of literacy and education), has not yet captured the real benefits that the telecentre can provide. Thus, greater resources in the continuous training in marketing skills should be provided to the RWA members. Greater awareness of the potential benefits that the centre can provide may stimulate grass root support and result in more innovative and profitable projects.

2. A leadership capacity that provides vision and support - Traditional leadership in rural communities may not be adequate or appropriate to implement a marketing driven E-commerce approach to trading. The community needs access to relevant leadership and leadership training to assist in pursuing technology- enabled opportunities as they emerge.

Thus, leadership training for the RWA executive should be implemented so that the centre's strategic vision can be realised. Furthermore, the leadership role 
in the future development of the centre, both in politi$\mathrm{cal} /$ financial and technical areas, must be addressed.

3. Linkage between the formal and informal system: programme development, management capability and evaluation criteria - To integrate and expedite the formal relationship of the centre with the RWA for funding and budget requirements and to ensure that the various components of the system work smoothly. At present, the centre has not established this formal relationship with the RWA and the issue of accountability must be addressed. The RWA is only this year implementing a formal budgetary system. Management skills and program development capability need to be expanded. A structured programme in the development of champions should be implemented to provide greater leadership and management functions in the centre. The " development " mindset that exists currently in the RWA requires a cultural shift. The lack of understanding in the overall business model and project sustainability (without marketing) are two main barriers for change in the RWA. Currently there is little understanding in the RWA of the linkage, interaction and impact of the various components of the marketing mix and how this equates to increased sales.

4. An application service provider (ASP) may be needed to complete the process. The ASP can provide and maintain the necessary software and hardware that link the telecentre to other users. The ASP can handle issues such as scalability, standard architecture, system design, data management and data transactions (for example, billing and payment using the RWA bank account), new application systems and software, and the integration with other systems. The ASP focuses on technical connectivity allowing the RWA to focus on its core competencies. Finally, in order for the telecentre to achieve its full potential as an integrator for greater economic benefit in the community it is necessary to address the issue of ease of use, training, governance structures and accountability, applied technical systems (integration of programme innovation and application providers) and sustainability.

Apart from developing a successful ICT strategy in these telecentres, it is necessary to examine how technology can enhance the marketing function in these rural centres. Generally the women understand marketing as a process where goods are taken to a physical designated place and where traders come to at a specific time and on a particular day to display and sell the goods. The research indicated that the RWA leadership had a basic understanding of marketing as a range of activities covering selling and promotion and identifying buyers (albeit it very restricted to the immediate marketplace).

The findings in this study revealed that there was inadequate market research performed to search for and identify buyers' needs. This is evidenced by the glut of products each year from the food security gardens. The glut causes low prices and difficulty in selling the produce (often it is left to rot). It must be noted that the RWA development model was not intended to be a commercial trading operation but to eradicate death by malnutrition (which has been successfully achieved). It is only at this stage of development that a migration path from self-sufficiency into profit orientation is being investigated. There is a lack of awareness about the potential benefits of market research.

Mchombu (2000) notes that it is difficult to provide information to women in small business because so little is known about how they seek information, how they use it and what problems they encounter. The RWA leadership sees market research as an expense without potential benefits. Although the RWA is well placed to uncover some of the market information there is a lack of formal structure and processing power to capture, manipulate and disseminate this vital information to maximise its potential to increasing market access. That is, data are gathered manually and transmitted orally. Without adequate information about what the market wants the RWA is unable to provide valueadded, innovative market demand products or services It is also unable to price its products and services accordingly.

Whilst the RWA executive members had some understanding of what competition is and how it impacts on their business they have not been able to relate it sufficiently to the marketing model and conceptually seem to "staddle" the development versus marketing ideology. Their local competitors offer discounts, credit and give " parties " to attract customers. The women feel this is not possible for them to do as they are funded with donor money, which must be spent directly on the projects. The leadership has not yet made the link between replicating their projects in surrounding villagers and creating increased competition in an already limited and impoverished market place. There appears to be an ideological struggle between development needs and the need to migrate income-generating projects into profit driven businesses.

Distribution of product is always a problem in a rural community. The difficulty with transport and the inadequate infrastructure, such as roads, have been some of the major barriers to market the products of the RWA. Without the knowledge and skills in business management, the RWA operators may not appreciate the relative importance of marketing, distribution and transport logistics to provide 


\section{Marketing in African Rural Women's Organisation}

an efficient and effective network. None of the project members (outside of the executive) had received any training in marketing yet they were responsible for marketing their goods and products.

Special attention needs to be applied to cultural and gender issues in RWA. The development model used by the RWA has focussed on gender empowerment and as a result the RWA has won tremendous respect from the local chiefs evidenced by the women's privilege of approaching the chiefs directly. Anecdotal evidence to support the above arguments are provided in Appendix 3

In order to provide a sustainable model for the RWA to provide continuing economic improvement, the integration of market information, leadership qualities and the telecentre operation should be adopted in order to establish some form of E-commerce activities. In E-commerce, barriers to entry are low, the transaction costs are lowered, customers have improved access to information and competition is high. The E-commerce can be channelled through the Internet in the telecentres and trade between supplier and buyer could be greatly enhanced. For example, the buyer can see where the supply is, its competitors, at what quality and price, and how to transport the purchase.

\section{Limitation of this study}

Although this study has captured the strengths and weaknesses of existing activities in the RWA, it has not addressed some of the external factors such as:- Political influences (e.g. government funding and initiatives), social expectations (e.g. change in mindset about quality vs. quantity and price and development versus profit): Technological innovations (e.g. broadband transmission of video images by fibre-optic cables): Economic growth (e.g. not affected by recession) and financial management skills (e.g. personnel in the RWA who are skilful in financial management of projects). Future studies can include all the above factors.

This study has focussed on the factors, which can transform from the self-sufficiency stage to the economic sustainability phase in the RWA. It may be necessary to move into the next stage of implementation in order to fine-tune the proposed model.

\section{Conclusion}

In conclusion, the above analysis demonstrates that the integration of ICT and marketing within the E-commerce framework has the potential to enhance trading activities and hence improve the economic well being of rural women. The RWA is currently trading in an impoverished market place (B2C) and as a result is unable to materially improve economic well-being. It seems that a transition to B2B in the main town of Pietersburg (90 minutes drive) may provide a more profitable market place. It may be that an E-commerce model can assist in the transition from B2C to B2B. E- commerce has the capability to improve market access through alleviating some of the RWA market weaknesses such as: Accelerating sales cycles as a consequence of being able to provide more timely information: Enhancing and expanding relationships and partnership networks through personalisation and customisation of all communication: Increasing levels of efficiencies in business transactions such as billing: Flexibility in repackaging products resulting from more accurate market information: Aggregating the RWA members products to secure large buyers: Providing 24 hour access to product information and cutting overall administration costs. However, the starting point cannot be simply E-commerce the process must begin with a business case that will set the ECommerce objectives and incorporate a community information network with the telecentre operation.

E-commerce models can provide a formal structure with processing power to capture, manipulate and disseminate the information needed to increase market access. The model has the capability to handle complexity and professionalise the business transacting processes of the RWA. It may be the vehicle needed to create the interaction between assets and markets whilst enhancing the efficiency of current business activities and transactions. However, information is only one resource amongst many required for successful development. Perhaps no single strand is sufficient and all are necessary and interrelated (Heeks 1999). If as Rosen (2000) believes an effective E-Commerce strategy is the intersection of a number of business strategies such as marketing, sales, operations, IT and customer service it is unlikely that ITC will be a sufficient condition for creating rural markets for economic upliftment. However if one considers technology as a process of knowledge in practice (Cypher) then it can be a short step to understanding that technology may be an important driver. Whilst the combination of marketing theory and E-commerce models may turn out to be very significant in the pursuance of sustainable economic growth it is unlikely that this is a complete model.

\section{References}

AFRE- FEM 1998. http://clients.tdg.ca/worldbank

Chen, S., Leteney, F., (2000), Get Real! Managing the next stage of Internet retail, European Management Journal, Vol. 18, No.5, p.519-527 
Rhodes

Cypher, M, (1997), The process of economic development. London, Routledge

Cunningham,M.(2000) Smart things to know about E-Commerce. Oxford. ,Capstone ,

Gurstein, M, (2000), Community Informatics: Enabling Community Uses of Information and Communications Technology, Boston, Idea Group Publishing

Hartman, A. (2000), Net ready, strategies for success in the E-conomy, New York, McGraw-Hill,

Heeks, R. (1999) Information and communication Technologies, Poverty and Development, Working paper No.5, Institute for development Policy and Management. Manchester University

Kotler .P, (1980). Principles of Marketing, Ed L. Stewart, New York, Prentice-Hall

National Telephone co-operative association (NTCA) (2000), Initial lessons learned about private sector participation in telecentre development, guide for policy makers in developing appropriate regulatory frameworks,.USA

Mchombu, C, (2000): Information needs of Women in Small Businesses in Botswana, The International Information and library Review, Vol. 32, No 1, March, pp39-67

Phororo, H and Prasad, G, (1996): Vegetable Marketing Study for Semokong Rural Development Project, Working paper number 7 , Roma: Institute of southern African Studies, National University of Lesotho.

Porter, M. (1985), Competitive Advantages of Nations, New York, McGraw Hill

Rappa, M, Business models on the web, http://Ecommercelbusiness models html.htm (last accessed March 27,2001

Rayport, J. The truth about Internet business models. http:/Www.strategy-buisness.com/briefs last accessed Jan 2001)

Rhodes, J.H. (2000). An Internet based model for building a local Commodity/trade exchange for a rural women's organisation. In the second international Get Smart Conference, Using community Informatics for regional transformation, Rockhampton Central Queensland University, Australia

Rosen, A. (2000) The e-commerce question and answer book a survival guide for business managers. New York, American Management Association

Rural Access to information and communication technologies (ICTs): The challenge to Africa, 2000, The Telecoms development group, Canada
Timmers, P, (2000). Electronic Commerce, Strategies and models for business to business trading. New York,. John Wiley and Sons

Turban, E, et al (2000) Electronic Commerce a Managerial Perspective, New Jersey Prentice Hall.

Weintraub, A (2001) The mighty mini-dots. BusinessWeek Asian edition. March 19th

Worldbank Poverty report (2000) accessed at: http://www.worldbank.org/poverty/wdrpoverty/report/7 last accessed on Jan $20^{\text {th }} 2001$ )

\section{Appendix 1: The Marketing model}

Kotler defines marketing as the human activity directed at satisfying needs and wants through exchange processes. Exchange is the act of obtaining a desired object from someone by offering something in return. Transactions are the exchange unit of measurement and the notion of multiple transactions leads to the concept of a market. A market is the set of all actual and potential buyers of a product. Markets develop in stages starting with self-sufficiency (which is the RWA position) where producers are ready to trade surplus. This can occur decentrally (where one seller sells to number of other self-sufficient traders), or it can happen centrally (where one merchant sells the surplus goods of many self-sufficient producers). Central marketing increases transactional efficiency by reducing the total number of transactions required meeting a given volume of exchange. It is the concept of markets that defines marketing. If a marketer does a good job of identifying consumer needs, developing products, pricing, distributing and promoting them effectively Kotler concludes that the goods will sell very easily. Kotler defines the basic model of marketing as involving the following tasks:

- Searching for buyers and identifying buyers needsMarket research

- Designing appropriate products (or modifying existing ones)

- Promoting products.

- Distribution of products. - Transport

- Communicating the product range and value to the target market.

- Pricing of the products.

- Service and after service.

This list is useful as a starting point to map what the existing RWA capabilities are in executing core-marketing activities. 


\section{Marketing in African Rural Women's Organisation}

\section{Market Research}

Searching for buyers and

identifying buyers needs

Identifying competitors

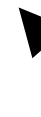

\begin{tabular}{|l}
\hline $\begin{array}{l}\text { Product Design } \\
\text { Designing appropriate products or } \\
\text { redesigning existing products }\end{array}$ \\
\hline $\begin{array}{l}\text { Product Promotion and communication } \\
\text { Advertising awareness } \\
\text { Image } \\
\text { Brand } \\
\text { Relationship building }\end{array}$ \\
\hline
\end{tabular}

Product pricing

What will the market pay?

Competition?

Value?

Distribution

Transport and delivery

Service and after service

Order processing

Billing

Queries

Problems

Figure 1. Kotlers Marketing Model

The diagram in Figure 1 was used in the research with the RWA leadership to discuss their understanding of a marketing model.
The human activity that results in satisfying needs through exchange processes
A market is the sum of the actual and potential buyers of a product.

\section{Appendix 2: An extended e-conomy business model - the infomediary (Hartman and Sifonis 2000)}

The infomediary model will be examined to explore how it can mitigate the problems of managing information for 


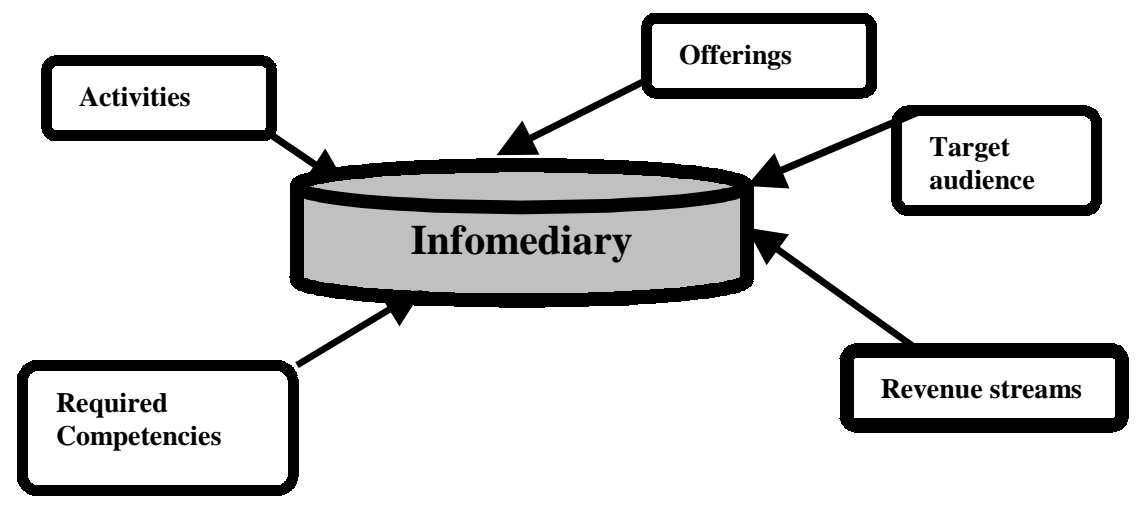

Figure 2. Hartman and Sifonis Infomediary model

marketing purposes. Hartman's (2000) infomediary model (below) is used here to illustrate the basis of a community based commodity exchange.

The infomediary is defined as an entity that brokers content, information, knowledge or experiences that add value to a particular $\mathrm{E}$ business transaction. It can also be termed a content aggregator that brings together buyers and sellers. The infomediary brings together buyers and sellers and provides value by offering advice and personal service. One of the major advantages of the model is that the infomediary does not need to own inventory or the means of production. However because it owns little the infomediary has to rely on partners to succeed. An infomediary will typically focus on developing numerous partnerships, developing extensive local content and promoting the web site to an ever-increasing number of buyers. An infomediary in effect creates an e-marketplace. Many examples of infomediaries can be found in the business world such as travel aggregators (www.travelocity.com) and NetBuy WwW.netbuy.com a business that enables real-time intercompany electronic supply chains through a comprehensive on line service for standard electronic components from a variety of suppliers. South Africa is beginning to see a number of infomediaries around the area of aggregating business suppliers. Currently Datatcentrix (Business Report) a local IT company is piloting a project to link all of South Africa's fast moving consumer goods retailers with distributors and suppliers via a central product catalogue. Whilst it describes itself as a Vasp (value added service provider) it is similar to an infomediary. A survey released by Sterling commerce (Business Report) found that over $25 \%$ of companies surveyed mentioned that they were planning to participate in an e-marketplace within the next year.

The infomediary model can support the marketing function in its capacity to provide extensive processing and commu- nication power thereby increasing transactional efficiency by reducing the total number of transactions required to meet a given volume of exchange. It is often the case that rural producers spend unproductive time trying to (often unsuccessfully) create markets for their produce and the time taken to market has to be taken from the time available to produce. In this model, local producers would need only to communicate with a central infomediary (The RWA) in place of decentral marketing.

The advantage for the infomediary is the opportunity to generate revenues for marketing activities and make a profit for the RWA, its members, local entrepreneurs and the telecentre through commissions from sales, subscriptions and membership fees and advertising. Figure 2 represents Hartman and Sifonis's infomediary model. The boxes connected by arrows into the centre of the diagram link what Hartman perceives as the key concepts of an infomediary model. This model will be used to map what the perceived RWA capabilities are in relation to the capabilities needed to implement an infomediary model.

Table 2 expands on the above model by considering each variable in the model and by looking at the RWA as an infomediary and at the potential activities and functions in each part of the model.

Primarily, the infomediary model offers a technological approach to creating markets by harnessing and disseminating information in a cost-effective way. Using technology successfully to provide a solution will include the incorporation of such factors as skill development, education and training into the model. This view fits with $\mathrm{Cy}-$ phers' (1997) who notes that technology is a difficult concept to define because it is not an object but rather, it is a way of doing things which translates to a way of thinking. He further states that "in a significant sense, then, it can be said that economic development is indistinguishable from the on going application of technological 


\section{Marketing in African Rural Women's Organisation}

\begin{tabular}{|c|c|}
\hline VARIABLE & THE RWA AS AN INFOMEDIARY \\
\hline Offerings & $\begin{array}{l}\text { Transport scheduling } \\
\text { Transporting opportunities for micro entrepreneurs } \\
\text { Aggregation services } \\
\text { Match making between buyers and sellers needs } \\
\text { Content around the economic structure of the region } \\
\text { Vocational skills training scheduling } \\
\text { Connection to poverty alleviation and economic empowerment } \\
\text { Government desks } \\
\text { Banking facilities } \\
\text { Financial transaction facilities } \\
\text { Notification services (when facilities, products and services are available) }\end{array}$ \\
\hline Target audience & $\begin{array}{l}\text { RWA members } \\
\text { RWA backed income generation projects } \\
\text { Government departments } \\
\text { Community residents } \\
\text { Wholesalers } \\
\text { Niche markets (e.g. organic vegetable retailers, Urban Diaspora) } \\
\text { Schools } \\
\text { Clinics } \\
\text { Hospitals }\end{array}$ \\
\hline Activities & $\begin{array}{l}\text { Leadership and negotiation } \\
\text { Banking facilities for transactions } \\
\text { (the trust infomediary) } \\
\text { Arranging transportation } \\
\text { Teaching marketing skills to the community micro entrepreneurs } \\
\text { Harnessing mobilising and organising community power } \\
\text { Bulk buying } \\
\text { Input provider (e.g. chicks vaccine, cement wire) } \\
\text { Lobbying local government }\end{array}$ \\
\hline $\begin{array}{l}\text { Competencies } \\
\text { required }\end{array}$ & $\begin{array}{l}\text { Billing } \\
\text { Order processing } \\
\text { Order fulfillment } \\
\text { Payment collection mechanisms } \\
\text { Computer literacy to update, expand and amend the web site } \\
\text { Human resources } \\
\text { Data collection- Access to indigenous knowledge } \\
\text { Inventory of local buyers and sellers } \\
\text { Negotiation skills } \\
\text { An understanding of marketing models } \\
\text { Multiple relationship management } \\
\text { Scalability to meet evolving challenges }\end{array}$ \\
\hline $\begin{array}{l}\text { Revenue streams } \\
\text { potential }\end{array}$ & $\begin{array}{l}\text { Discounts from suppliers } \\
\text { Commissions from sales } \\
\text { Government Tenders } \\
\text { Subscriptions }\end{array}$ \\
\hline & Table 2: The RWA as an Infomediary \\
\hline
\end{tabular}

on going application of technological knowledge to production "(pp 404). And that in the absence of a continuous application of technological change development will inevitably falter.

\section{Appendix 3: Anecdotal evidence from the RWA executive supporting the re- search discussions}

\section{Understanding of email and the Internet}

"It is talking to people to share information, to talk about problems and identify solutions"
"We can use it when we want to communicate with people far away and do not want to use the post"

"We can advertise ourselves and get to use other peoples experience".

" Connecting to government and businesses and getting information on what people want, who can buy what and from where.

"To find cheaper raw materials" 


\section{Leadership}

" The problems of tribal fighting, jealousy and self interest can kill an organisation. It is not possible to train all the women involved to drive one car at the same time and those that are learning to drive cannot learn to drive competently without extensive training and mentoring. Therefore it can kill an organisation to elect women into leadership roles who have not been trained"

\section{Marketing activities}

"We put up posters and we travel to villages telling people about us"

"We give brochures to all drivers and vehicles that come through the village"

"We have a list of telecentre services up outside the telecentre"

"I do promotion, I give free juice with a plate of food and free custard and Jelly to get people to come to the restaurant"

" I go to funerals and weddings with no invitation and I watch what they do, how they do it and ask how much they are being charged, then I look at my own catering and see how I am doing"

\section{Reasons why customers choose RWA prod- ucts}

"People buy from us because they know that buying from us supports the development of the village"

"Buying from us results in more women being educated and having the opportunity to start their own business"
Understanding of marketing principles

" We are part like a business and part not like a business"

" To do marketing we must sacrifice for sustainability as money will be spent on marketing and not on more stock"

\section{Gender empowerment}

" Sister Lydia cleared the way for us by getting access to land and we now legally own the land. Now we go directly to the chiefs when we need to talk to them, we do not need any more to go through the men to talk to the chiefs, other people and the men have to talk to the chief through the councillors"

\section{Information needs}

"Where can we find cheaper suppliers for our projects?"

"Where can we find prices on things?"

"Where can we get information on what people wan to buy?"

"Information on local government building and development projects such as low cost housing, clinics and hospital projects"

"We don't know how to find out who else we can sell to?"

" How can we find out where to find wholesalers and transport? 